\title{
Correction to: DC-SIGN-LEF1/TCF1-miR-185 feedback loop promotes colorectal cancer invasion and metastasis
}

\author{
Menglang Yuan · Xinsheng Zhang · Jingbo Zhang $\cdot$ Keyong Wang $\cdot$ Yu Zhang $\cdot$ Wei Shang $\cdot$ Yinan Zhang \\ Jingyi Cui $\cdot$ Xiaomeng Shi $\cdot$ Heya Na Deyu Fang Y Yunfei Zuo - Shuangyi Ren
}

Published online: 4 March 2021

(C) The Author(s) 2021. This article is published with open access

\section{Correction to: Cell Death \& Differentiation \\ https://doi.org/10.1038/s41418-019-0361-2}

The original version of this article unfortunately contained a mistake. Since online publication of this article, the authors noticed that there was an error in Supplementary Figure $7 \mathrm{~b}$. An incorrect image was used in invasion panel for DC-SIGN+miR-185. The image has been updated online.
Open Access This article is licensed under a Creative Commons Attribution 4.0 International License, which permits use, sharing, adaptation, distribution and reproduction in any medium or format, as long as you give appropriate credit to the original author(s) and the source, provide a link to the Creative Commons license, and indicate if changes were made. The images or other third party material in this article are included in the article's Creative Commons license, unless indicated otherwise in a credit line to the material. If material is not included in the article's Creative Commons license and your intended use is not permitted by statutory regulation or exceeds the permitted use, you will need to obtain permission directly from the copyright holder. To view a copy of this license, visit http://creativecommons. org/licenses/by/4.0/. 